\title{
Why theory matters: Analytical strategies of Critical Psychology
}

\author{
A importância da teoria: estratégias \\ analíticas da Psicologia Crítica
}

Ernst SCHRAUBE ${ }^{1}$

\begin{abstract}
Based on Critical Psychology from the Standpoint of the Subject the article describes analytical concerns and strategies of critical psychology. In a first step, the development of critical psychologies is located in current discussions on the production of knowledge, and three different typical approaches and major steps toward situated critique as a practice of mutual recognition are delineated. This shift, it is argued, has led to a historically new relevance of critique, and two basic analytical elements of critical research are introduced: Everyday conflictuality as the initiating moment of critique as well as the importance of theory for critical inquiry. On this basis a variety of analytic strategies and concepts are presented which inform Critical Psychology from the Standpoint of the Subject and suggest a constituent move from partial perspectives toward situated generalization.
\end{abstract}

Keywords: Critical Psychology; Psychological theories; Subjectivity.

\section{Resumo}

O artigo descreve preocupações e estratégias analíticas da Psicologia Crítica com base na Psicologia Crítica sob o Ponto de Vista do Sujeito. O primeiro passo consiste em situar o desenvolvimento das psicologias críticas nas discussões atuais sobre a produção de conhecimento e delinear três abordagens típicas diferentes e passos principais para a elaboração da crítica situada como prática de reconhecimento mútuo. Argumenta-se que esta mudança levou a uma pertinência historicamente nova da crítica, e dois elementos analíticos básicos da pesquisa crítica são introduzidos: conflitualidade diária como o momento que inicia a crítica e a importância da teoria para a investigação crítica. Assim, apresentamos uma variedade de estratégias e conceitos analíticos, informando a Psicologia Crítica do Ponto de Vista do Sujeito e sugerindo um movimento constituinte das perspectivas parciais à generalização situada.

Palavras-chave: Psicologia Crítica; Teorias psicológicas; Subjetividade.

Although throughout the history of the sciences critique has played an essential role in the development of knowledge, it remains a struggle for post-1945 conventional Western psychology until today to incorporate the potential of critique into its theory, methodology and research practice.

\footnotetext{
$\boldsymbol{\nabla} \nabla \boldsymbol{v}$
}

1 Roskilde University, Department of Psychology and Educational Studies. Universitetsvej 1, 4000, Roskilde, Denmark. E-mail: <schraube@ruc.dk> 
However, from the late 1960s, a plethora of critical psychologies emerged which extensively integrate critique into their approaches. In recent years, these have developed from more local initiatives toward more systematic interconnected dialogues around the world. Journal special issues, for example, collect and trace the development of critical psychologies in countries around the globe (Dafermos, Marvakis, \& Triliva, 2006; Dafermos, Marvakis, Mentinis, Painter, \& Triliva 2013); furthermore the recently published voluminous "Encyclopedia of Critical Psychology" (Teo, 2014a) as well as the "Handbook of Critical Psychology" (Parker, 2015) invite mutual collaboration and elaborate the fundamental significance of critique in the development of psychological knowledge.

As diverse as the various critical approaches may appear, through acknowledging that human life in the contemporary world is inherently conflictual, they also share a common analytical concern leading them to reject measuring the human mind, thinking in scales, or categorizing and regulating individual behavior as the most suitable approach to psychological issues. Instead, they call for engaging in the development of a substantial analytical vocabulary capable of exploring and collectively locating everyday conflictuality in its social and material relations as a basis for realizing the possibilities for change. The concept "concientization", for example, articulates this shared analytical concern focusing, as Guzzo (2014) explains, on "the process of becoming aware of something" (p.300). Or in the words of Martín-Baró (1994): "Concientización ... [involves] a move [of people toward] a critical understanding of themselves as well as their world and where they stand in it" (p.39).

In the following I present some analytical strategies and concepts for "processes of becoming aware of" from a specific perspective of critical psychology and a tradition which, since it radically roots its inquiry in the perspectives and standpoints of human subjects, describes itself as a Psychology from the Standpoint of the Subject. This direction of critical psychology has its origins in Europe, fundamentally collective in its orientation, the work of Klaus Holzkamp has played a pivotal role in its development. First, I situate the development of critical psychology (in a broader sense) in current discussions on the production of knowledge and delineate three different typical approaches and major steps toward a situated critique as a practice of mutual recognition. In connection with this shift, I argue for a historically new relevance of critique and then introduce two basic analytical elements of critical research: Everyday conflictuality as the initiating moment of critique as well as the importance of theory for critical inquiry. On this basis I present a variety of analytic strategies and concepts which inform critical psychology from the standpoint of the subject and indicate the constituent move from partial perspectives toward situated generalization.

\section{Toward situated critique as a practice of mutual recognition}

Over the past decades, a fundamental epistemological shift from a god's eye view toward situated knowledge has crystallized in the theory of science and the understanding of the practice of developing scientific knowledge. The idea of conducting scientific research from an external, abstract and universalistic perspective, disconnected from specific historical and societal relations is now challenged. Scholars realize their research activities and practices of developing knowledge do not occur in a social vacuum, but are rooted in the world, a world involving other human beings as well as societal relations, culture, technology and nature. Through their research and production of knowledge, researchers are not only participating in the creation of the social world, but also view the social world in turn as affecting their research practices, including their theories, concepts, methodologies as well as their own thoughts, ideas and conduct of life.

Especially Science Studies contribute to an appreciation of this epistemological shift. Analyses in this field offer a detailed picture of the fiction of scientific research from an external perspective 
disconnected from the sociomaterial realm. As historian of science Haraway (1991) explains, this fiction is a "god trick", a "view from above, from nowhere" (p.195) and she argues for an understanding of the "embodied nature of all vision" (p.188). In a body of theoretical work as well as extensive empirical explorations of the practice of scientific research and the production of knowledge, science studies substantiate how scientific work is inherently a worldly situated, an embodied, a socially and culturally constructed process (Hess, 1997; Knorr Cetina, 1999; Latour \& Woolgar, 1986; Restivo, 1988).

Accordingly, we can identify a move within a variety of disciplines in the humanities, social sciences and natural sciences away from abstract, infinitive vision toward a socially situated understanding of knowledge which includes a systematic reflection on the social, cultural and material mediation of scientific theory, methodology and research practice.

However, the god's eye view as a socially disembodied research practice still generally represents the unquestioned model of scientific research in conventional Western psychology since 1945. In fact, its theoretical and methodological vocabulary - including the classical and still dominant experimental-statistical methodology - embodies epistemological strategies virtually disarticulating the social situatedness not just of the researcher but also of the psychological phenomena under investigation.

How is such a disembodying research practice established in conventional approaches? Instead of developing its own, genuinely psychological theoretical concepts and methodologies, conventional psychology imports its research vocabulary from the natural and technical sciences (e.g., gestalt psychology borrowing from physics, behaviorism from physiology, or cognitivism from computer sciences). Within such a natural science based theoretical and methodological framework (actually it represents not a genuine natural science research vocabulary; if it were, it would have to be argued how the theoretical concepts and methodology fit to the subject matter of the research), the psychological production of knowledge is structured from a view from above, from an external, scientific third-person standpoint. In such a perspective, the complex relationships between humans and the world are reduced to causal if-then relations and ideas of linear determination prescribing an understanding of the world as stimuli creating effects in the individual, and radically foreshortening human subjectivity. The human being seems to be solely dependent on external factors, merely responding to stimuli. In adopting such an approach, psychology not only establishes the research position of a distant judging observer, but also a model of passive research objects - and ultimately completely disregards human subjectivity. The complexity of the sociohistorical world as enacted, experienced and debated by living persons is reformulated in experimental operationalizations as psychological variables unaffected by the world. Human subjects appear as individually isolated units, as if acting in a vacuum and without social lives, real life context, and ways of constructing meaning in the world. In this sense, conventional psychology's vocabulary and research practice not only lost sight of the subjective dimension of human life, it also became socially disembodied and worldless (in detail, Holzkamp, 2013d, p.234; 2015; Schraube, 2003; Tolman, 2001)

Such a conceptual twist of systematic worldlessness paired with the exclusion of subjectivity establishes the particular nature of the external, socially disembodied research perspective of conventional psychology. Since such an epistemic practice disconnects psychological phenomena from the contexts and social realities where they actually unfold, it confronts us with the dilemma of not knowing what the phenomena and problems under study are part of and connected with, and in this way undermines the development of any substantial knowledge on how to facilitate movement for psychological problems and frozen relations in everyday living.

Since the 1970s, as psychologists have become increasingly aware of these epistemological dilemmas in psychological research practices, a 
variety of alternative approaches have emerged parallel to conventional psychology (a process actually ongoing throughout the history of academic psychology). These approaches range from phenomenology (Giorgi, 2009), feminist psychology (Wilkinson, 1986) and cultural-historical activity theory (Wertch, 1991) to cultural psychology (Valsiner, 2014), discursive psychology (Harré, 1979) and social-constructionism (Gergen, 2009), which all offer different variations of this move from an external, socially disembodied epistemology toward a psychology with its theoretical and methodological vocabulary rooted in the social world and applying world-situated research practices to developing psychological knowledge.

Three major visions of critique in the development of critical psychology

This epistemological shift is also visible in the formation of critical psychology. In Germany, to take an exemplary case, we can differentiate three interrelated major visions of critique in the development of critical psychology with an accompanying move from a more external and abstract critique toward situated critique.

In the context of the student movement in the late 1960s, a line of critique emerged directed against psychology as a whole which involved a specific kind of anti-psychology. Through critical studies of the role of psychology in society and especially in the field of work including the military, students came to realize that the production of psychological knowledge is by no means valueneutral. Instead, it is intimately connected with ruling relations in capitalist society and the knowledge developed is directly serving capitalist interests. The only adequate solution appeared to be to dissolve academic psychology as a whole, and Zerschlagt die Psychologie! (Smash Psychology!) became the motto of the day. In May 1969 at the University Hannover for example, at one of the largest conference on critical psychology during the student movement, a final declaration described psychology as a lost cause, a hopeless un-political or integrating system-induced contradictions, and ended with a call to disband psychological departments and "Smash Psychology!" (declaration reprinted in Rexilius, 1988, p.408). A number of students as well as faculty members actually followed the suggestion of quitting their studies and jobs to join the working class in their revolutionary struggle. As important as this vision might have been in putting on the agenda the capitalist mediation of knowledge production and psychological research's social relevance and knowledge interest, it nevertheless remains within an abstract and external perspective, unable to turn this critique into a critical psychology situated in the contemporary world and profoundly concerned with addressing and transforming its conflictuality.

In response, a second major vision of critique emerged centering on the conflictuality of the social world by developing critical psychology as a critique of society. The focus of psychological critique here is on the critical analysis of societal conditions including ideology and discourse, not only as an attempt to uncover and provide evidence for the social, ideological and discursive character of psychological theory and methodology and how they legitimize existing social relations, but also to contribute critical knowledge to an understanding of the specific situations in which human subjects live their everyday life. As one of the founding editors of the journal "Psychologie und Gesellschaftskritik" (Psychology and Critique of Society) Grubitzsch (1988) explains: "We wanted critical Aufklärung of present conditions ... and [a critical psychology] which illuminates existing social relations in their daily structures of power, their patterns of political legitimation and their creation of ideology ... we wanted a psychology which critically participates in the development and change of society from below" (p.91; author's translation). But this step also remains abstract in a certain way, still partly caught in an external, socially disembodied perspective since it leaves psychology itself untouched and fails to engage in any renewal and conceptual rebuilding of psychological theory and methodology. Given this lack of re-conceptualization, the critical revelatory insight into social conditions 
has to draw on already existing psychological frameworks, including their disembodying limitations.

A third major vision of critique tries to address this limitation by not solely focusing on a critique of society, but on a critique of psychology seeking to fundamentally rethink and rebuild psychological theory, methodology and research practice. Critique here does not reject psychology, but aspires to a unity of critique and further development capable of contributing to a new, critical, situated and socially embodied conception of psychology. The exceptional body of work by Klaus Holzkamp and his associates is located within this vision of critical psychology. Drawing on cultural-historical activity theory, they tried to renew psychological vocabulary not only by critically redefining singular concepts (as for example perception, emotion or motivation), but by developing a systematically founded and integrated theory of human subjectivity, including its various psychological dimensions (Holzkamp, 1983a; Schraube \& Osterkamp, 2013; Tolman, 1995). The aim was not just to develop a new theoretical framework for critical psychology, but to contribute to the development of psychology in general through a seminal renewal of its conceptual foundation. As a result, a detailed Psychology from the Standpoint of the Subject was developed redefining psychology as a historically developed theory about subjects as societal beings and re-constituting it as a science for and about these subjects (detailed discussion about various lines of critique in psychology see e.g., Dafermos \& Marvakis, 2006; Fox, Prilleltensky, \& Austin, 2009; Guzzo, 2015; Hook, 2004; Lacerda, 2013; Mattes, 1985; Parker, 2015; Sloan, 2000; Teo, 2005; 2014b).

These different visions of critique indicate a fundamental analytical shift to a psychological theory and practice increasingly rooted in the contemporary world and in the social, cultural, material and discursive realities where the psychological phenomena actually unfold and in and through which human subjects - including the researchers -, conduct their everyday life (see also Teo, 2015). In this sense we can see here a move toward a radically situated critique as a practice of mutual recognition (in more detail below), a move also more generally visible in the various critical psychologies currently flourishing around the world.

\section{Analytical strategies and concepts of situated psychological critique}

But how to practice situated critique in psychological research? Are there helpful analytical strategies and concepts to work with? Rather than critical research merely requiring some fixed procedures to be followed, the respective research issues and questions determine how the investigation is structured which, in turn, requires an open process of continuously rethinking adequate research strategies and concepts. Moreover, since both the researcher and the phenomena under investigation are inevitably part of the social world, we actually have to pull ourselves up by our own bootstraps. As Holzkamp (1983b) explains:

Science is not the result of somehow trying to apply fixed procedures. It must be seen as a never-ending acquisition of human knowledge, an enduring struggle with narrow-mindedness, superficiality, and false knowledge. Science is a permanent questioning of the apparently obvious. In principle, it means swimming against the stream, which also means swimming against the stream of our own prejudices ... Science is critique and at the same time self-critique (p.163; author's translation).

However, describing situated critical research as a genuinely fluid, open and explorative activity does not mean that research is an entirely undefined process without any theoretical and methodological conceptions - quite the contrary, to be able to pull ourselves up by our own bootstraps, we need a framework of analytical strategies and concepts. Drawing on the tradition of critical psychology from the standpoint of the subject, I will now focus on two aspects of just such a framework: On the question what initiates and fuels situated critique as well as on the importance of theory. 
Everyday conflictuality as the starting point of situated critique

What is the starting point of critical psychological research practice? Critique is always directed against something, and this "something" inevitably relates to problems and concerns in the everyday world. Most critical psychologists would agree that problems in the practice of everyday living - dilemmas and conflicts in everyday experience, activities, common sense or other everyday actualities -, establish the starting point of any critical research. As Teo (2015) notes: "Instead of making individuals and groups into problems, CP [critical psychology] attempts to work on problems that individuals and groups encounter in a given society" (p.4). But what is a problem? Can we say something more general about its constitution? This is a crucial question, since the research problem not only initiates but also fuels and directs our critical inquiry. Many critical researchers would describe "inequality in human relations" as a major concern of their critical inquiry, or constellations of "subjugating others", or any kind of "coercion", "existential suffering", "reification", "destruction of life", or, to use a formulation of Marx (1981), "all relations ... in which the human being is a humiliated, enslaved, abandoned, miserable creature" (p.385; author's translation). If we try to generalize and find what the various specific concerns have in common, we might define the general characteristic of a problem and initiating momentum of situated critique as any one-sided views and centered practices in everyday living, effective in the past, present or future, which reduce inter-subjective relations and undermine the mutual reciprocity of human relations, not only in lived relations, but also embodied in theoretical concepts, social institutions, or technological artifacts.

Yet even when we take the problems and conflictualities of everyday living as a starting point, how can we explore these issues critically? Here, aside from phenographic descriptions, empirical explorations and various other analytical strategies, theory has a particular importance in critical research practice. In conventional psychology, there is little empirical research. As mentioned above, the theoretical and methodological vocabulary is adopted from the natural and technical sciences, and taken as appropriate for psychological subject matter without any systematic foundation or discussion to justify their use. "Psychologists", Danziger (1997) notes, "tend to proceed as though everyday psychological categories represent natural kinds" (p.8). However, the theoretical vocabulary is the medium of the human power to think and essential in any process of developing (scientific) knowledge. As Vygotzky (1927/1997) emphasizes:

Everything described as a fact is already a theory ... When we meet what is called a cow and say: 'This is a cow,' we add the act of thinking to the act of perception, bringing the given perception under a general concept ... I do not see that this is a cow, for this cannot be seen. I see something big, black, moving, lowing, etc., and understand that this is a cow. And this act is an act of classification, of assigning a singular phenomenon to the class of similar phenomena, of systematizing the experience etc. Thus, language itself contains the basis and possibilities for the scientific knowledge of a fact. The word is the germ of science and in this sense we can say that in the beginning of science was the word (p.250).

Every empirical reality is never perceived just as such, but always through the available language and theoretical concepts which, in turn, affect our views of the world and, thus, our relations to it. In this sense, psychological research does not just reflect reality but virtually creates reality through the way it conceptualizes it. But it is not only critical research that requires theory and concepts, but every form of empirical research since otherwise it would be lost in pure sensations and would be unable to meaningfully access and analyze reality. In the words of Danziger (1997): "Every empirical description is an account that has been organized in terms of general categories. These categories define what it is that is being observed" (p.7). Theoretical concepts and categories represent the fundamental prerequisite of the development of 
knowledge but also incorporate - through its socially situated nature-, politics of knowledge (Papadopoulos, 2009; 2011). Furthermore, without inherent reference to the phenomena, they lack any analytical power. Therefore, it is crucially important to carefully develop and continuously refine a psychological vocabulary that embodies the analytical capacity to grasp the psychological subject matter. For this reason, it not only has to constitute a central field of study within critical psychology, but within psychology in general. Klaus Holzkamp realized the significance of this task as few others have, and placed it at the very center of his academic engagement. His work has inspired a tradition of critical psychology that contributes to a systematic founded theoretical and methodological language for psychology. I will turn now in more detail to the theoretical framework of this tradition of critical psychology from the standpoint of the subject and present some of the basic concepts and analytical strategies of its approach.

\section{Theorizing psychological phenomena}

from the standpoint of the subject

One of the most interesting qualities of the psyche is its ability to mediate between the individual and the world. All psychological functions, such as experience, emotion, thought and action, constitute the fundamental prerequisite for the human being to be able to live in a societal world together with others. Consequently, the question of understanding the relationship between individual and society lies at the heart of critical psychology and its conceptualization of psychological phenomena. In taking everyday experience and conflictuality as the central concern of critical research, the theoretical framework should serve as a tool to analytically engage in a collective dialogue and a situated, contextual understanding of the concerns and challenges of human subjectivity and the conduct of everyday life.

Today, no one would seriously doubt that individuals live their lives in a societal world. It is just as impossible to imagine people without a society as a society without people - and highly unlikely that such a statement would raise any eyebrows in conventional psychology. However, as already mentioned, mainstream psychology solely views society as an environment that has a causal effect on people. This becomes evident, for example, in the if-then structure of traditional methodology, where the world appears as a stimulus acting on the individual and eliciting a particular response (for a detailed discussion, see Holzkamp, 2013d; Tolman \& Maiers, 1991). Critical psychology challenges this conception of purely conditioned people and what it terms the conditioning discourse of dominant psychological models. In contrast, it argues that this relationship has to be understood as two-sided. Not only do we live under particular conditions, we also create the conditions under which we live. This insight into the two-sidedness of human life is a fundamental principle underlying critical psychology, and has to be systematically included in the formation of its psychological concepts and theoretical language.

Here the close relationship to Marx's social theory becomes apparent, since Marx argued that the particularity of human beings in relation to other creatures lies in the fact that they themselves produce the societal world in which they live their life. As its central task, Marx's theory seeks to elaborate the overall societal coherence of this relation between the production of the societal world and the conditions of human life. Critical psychology takes up this basic idea in Marx's writings, seeking to develop a psychological conception systematically elaborating the subjective dimension of this relation between societal production and the conditions of human life.

In this project, Holzkamp's (1983a) volume "Grundlegung der Psychologie" (Foundations of Psychology) represents an important step. Inspired by Leontyev's (1981) "Problems of the Development of the Mind", Holzkamp attempts, through a historical reconstruction of the phylogenetic and socio-historical development of the psyche, to develop an integrated set of psychological concepts cogently articulating the inherent relations between individual and society (summary in Holzkamp, 2013a; 2013b; Tolman, 1994). His analysis demonstrates in detail that the potentiality of 
human subjectivity and agency is not the product of isolated individuals preserving and developing their own lives. Instead, human agency only develops its potential through individual subjects gaining collective influence over the particular societal conditions which are specifically relevant in their shared conduct of everyday life. Consequently, the quality of each individual's lived experience is inherently connected to the type and degree of agency which that individual can exercise. Human conflictuality, suffering and fear do not solely originate from immediate constraints, but are the result of individuals at the mercy of social relations they are dependent on, removed from any influence over them. Hence, to overcome suffering and develop a genuinely human quality of life it is not enough just to satisfy and ensure immediate needs; rather, it requires the individual subjects' possibility of influencing and participating in the shaping of the conditions on which their conduct of everyday life depends.

As a central dimension of the relationship between individual and society, critical psychology identifies the subjective reasons for action, a concept opening up an alterative perspective to the classic conditioning model. Rather than social conditions merely acting causally to determine how individuals experience or act, human beings actually conduct their lives within a context of interwoven and interrelated societal meanings. But human experience and action are not mechanistically effected and determined by societal meanings; instead, that experience and action is grounded in each individual's interest in gaining a degree of influence and control over the societal conditions of her/his development and quality of life. As structures of social meaning, the pertinent conditions flow into the premises for each person's subjective reasons for action. By recourse to these premises, individuals perceive their own actions as grounded and evaluate how far the pertinent conditions reflect their own life interests, or their need to act individually or collectively to increase their influence and control over the societal conditions of their development and quality of life.

Once critical psychology had elaborated the

540 crucial role of subjective reasons for action in human subjectivity and the conduct of everyday life, it proposed a reason discourse (in opposition to the conditioning discourse of conventional psychology) as the discourse most adequate to the task of formulating genuinely psychological theories and methods. The reason discourse, though, requires a radical epistemological shift in psychological theory and research practice. Since reasons for actions are given in the first-person, they are always my reasons, reasons from each individual's standpoint and perspective. Therefore the traditional god's eye view and external scientific standpoint of research (as practiced in the conditioning discourse) has to be replaced by a situated approach from the standpoint of the generalized subject. Martín-Baró (1994) realized the significance of such a shift when he emphasized: "We have to redesign our theoretical and practical tools, but redesign them from the standpoint of the lives of our people: from their suffering, their aspirations, and their struggles" (p.25).

It would be a misunderstanding to interpret the first-person perspective as an individualistic, subjectivist concept. On the contrary, it allows important clarifications in the understanding of human sociality. Since "I" experience myself and the world from my perspective, and act in the world from my perspective and standpoint, then logically the other also experiences her/himself and the world from her/his perspective and acts from her/his perspective and standpoint in the world. This means we do not just simply react to what others do (as if their actions were causes to our reactions), but we have a meta level at our disposal: we perceive the other subjects as reflexive subjects that perceive us as reflexive subjects. So we always assume other's agendas, perceptions, etc. - and do not just react to some behavior of theirs. We know that we have reasons to act in a certain way and assume others have those too (even if they are not always obvious to us). And we negotiate such reasons with ourselves - as we act -, and assess our possibilities. And we can communicate them - make them understood to others -, and ask others about their reasons.

This symmetrical reciprocity of the subjects' first-person perspectives and intelligibility of reasons 
is an essential prerequisite for any form of social interaction. Hence, it is precisely the systematic inclusion of the subject and recognition of the other as coequal center of intentionality and the origin of her/his agency that facilitates a decentered, intersubjective symmetrical understanding of human sociality based on the multiplicity and reciprocity of perspectives and standpoints (Schraube, 2013; 2014). Therefore the suggestion is not to investigate the subject or subjectivity as the object of research, but to take it as the very standpoint of research itself. Here we can see a specific variation of a situated critique as a practice of mutual recognition. The suggestion of rooting psychological research in the standpoint and perspective of the "I" and "we" facilitates an exploration, through subjective experiences and conflictuality, of what the world means for human subjects, and their possibilities and necessities to act - and hence this tradition of critical psychology describes its approach as a psychology from the standpoint of the subject (Holzkamp, 2013c; Osterkamp, 2009; 2015)

From the perspective of the standpoint of the subject, the challenge, or momentum that drives human subjectivity and the conduct of everyday life is located precisely in the two-sided relationship between individual and society with its contradiction between, on the one hand, individuals being subject to the conditions under which they live, and, on the other, their possibility of influencing and changing these conditions to reflect their own needs and interests. To express this fundamental contradiction in human agency, which can be found running through the various psychological phenomenon and everyday practices, critical psychology developed the dual concept of restrictive versus generalized agency. Depending on the situation, in seeking to overcome this contradiction, subjects may not only have reasons for trying to change particular conditions to favor their life interests, but equally have reasons to accommodate themselves to given possibilities, for example, when attempting to intervene and change the situation appears to carry a significant risk of conflict with instances of power. From the subject standpoint, this creates the dilemma that the propensity to secure one's own situation (in the short term), ends up undermining one's own prospect of generalized agency, and violating one's own long-term interests.

The central driver for empirical research within critical psychology from the standpoint of the subject is to engage with people on an intersubjective basis and to explore their conditions and inherent possibilities and limitations of action in order to open up perspectives towards change and generalized agency. For this reason, the subjects of research are defined as co-researchers, as they are the source of knowledge about and insights into the conditions, meanings and reasons that surround the problem at the heart of the research engaging with the practices they are involved in. In this sense, the research practice is essentially participatory and cooperative, enacted and guided by the involved subjects (e.g., Axel, 2011; Dreier, 2008; Haug et al., 1999; Højholt, 2015; Kousholt, 2015; Nissen, 2012; Stephenson \& Papadopoulos, 2006). The aim is to develop a collaborative understanding of the questions and problems at the heart of the research, to generalize subjective experience, as well as to open perspectives towards generalized agency.

\section{From partial perspectives toward situated generalization}

With a situated perspective of developing scientific knowledge, critique receives a historical new relevance. As soon as we realize that any research activity is worldly situated and embedded in specific socio-historical relations, we become aware that all scientific vision, including research questions, theoretical concepts, methodologies, observations etc., is limited, partial, based on specific assumptions and unavoidably prejudiced. Consequently, continuous critique and self-critique are indispensable elements in any production of scientific knowledge. However, acknowledging that the production of knowledge is located within partial perspectives does not inevitably imply that we must fall back on a radical subjectivism. On the contrary, it is precisely the task of critique and selfcritique to address partiality and subjectivism - and 
transcend it. Thus, the underlying analytical direction of situated critique is from partial perspectives toward situated generalization.

In this final section, I would like to offer an insight into this central analytical move of critical knowledge in psychological research practice. Critical inquiry starts from an exploration of partial perspectives and the subjective dimension of human life with, as mentioned above, the initial moment of research rooted in conflictuality and concerns in everyday experience, thought and action. Usually, the subjective voicing of specific conflictual experiences in everyday living is not only articulated in words, but also expresses ideas and understandings - everyday theories and knowledge -, about the conflictual phenomena, and so already represents a step towards situated generalization. Therefore, one important analytical strategy of situated critique is the detailed phenographic descriptions of conflictual phenomena from the various perspectives involved. Situated critique engages in everyday experience and knowledge and takes them seriously. It realizes, that subjective experience, thought and action reference to our common world, though in limited, partial and often quite contradictory ways; and that we cannot recognize immediately the nexus between subjective experiences and the fabric of the social world including its possibilities and limitations for action. Exactly because of the partiality and immediacy of everyday experience we need scientific research. Therefore situated critique engages in everyday experience, thought and action, including their partiality and contradictions. However, not in an individualistic-personalizing way, instead it tries to make them understandable in their socio-historical connections and contexts. This task requires theory. So in addition to the phenographic analytical dimension, situated critique also builds on a theoretically informed constructive analytical dimension as the central moment of "pulling ourselves up by our own bootstraps".

The analytical move from partial perspectives towards situated generalization also shapes the construction of the theoretical concepts of situated

542 critique as they seek to overcome one-sided and partial perspectives, and incorporate the essential aspects of the reality they refer to. The concepts mentioned above, for example, "reason discourse", "first-person perspective", "subjective reasons for action" or "restrictive versus generalized agency", all systematically integrate the subjective dimension in psychological vocabulary (even structuring them from the standpoint of the subject), hence including the dimension not articulated in the basic concepts of conventional psychology. Theoretical concepts derive their analytical power from the extent of their embodied situated generalization. The generalizing efforts inscribed in the concepts help to reflect and analyze subjective experience, thought and action, and open up a dialogue for understanding the everyday conflictuality in its social and material contexts.

Situated generalization is a continuously ongoing process which is never finished. As a result, the theoretical concepts developed can reach a certain level of clarity and stability, but are never absolutist. The relatively stabile and saturated basic concepts of critical psychology from the standpoint of the subject always need to be expanded and refined in relation to specific localities and fields of practice. An extensive body of research in various fields of practice (ranging from clinical practice and educational institutions to work, organization and technology in the practice of everyday living) draw on or are rooted in this conceptual framework of critical psychology, and re-shaping and further developing its theoretical, methodological and empirical approach (detailed summaries and collections of recent work, e.g., Allespach \& Held, 2014; Motzkau \& Schraube, 2015; Painter, Marvakis, \& Mos, 2009; Reimer \& Markard, 2014; Schraube \& Højholt, 2015). A challenge here is to expand and refine the theoretical vocabulary in such a way, that it also enables to critically analyze partial perspectives, interests and politics embodied in societal institutions and technological artifacts as well as to open up perspectives for a generalizing transformations of social and material relations.

Situated generalization thus aims to overcome the conventional dichotomy between subjective experience and scientific objectivity. In 
this approach, though, generalization and scientific objectivity is not attained at the cost of the subjective and by disarticulating the subjective dimension of human life, but rather through the generalization of the subjective. Thus, the strategies of critical knowledge not only start but also end in the subjects' everyday living - and it is here that the decision is taken on the potential of the analytical efforts in the "processes of becoming aware of" and in the "move of people toward a critical understanding of themselves as well as their world and where they stand in it".

\section{References}

Allespach, M., \& Held, J. (Eds.) (2014). Handbuch Subjektwissenschaft. Ein emanzipatorischer Ansatz in Forschung und Praxis. Köln: Bund-Verlag.

Axel, E. (2011). Conflictual cooperation. Nordic Psychology, 63(4), 56-78.

Dafermos, M., \& Marvakis, A. (2006). Critiques in psychology: Critical psychology. Annual Review of Critical Psychology, 5. Retrieved February 1, 2015, from www.discourseunit.com/arcp/5

Dafermos, M., Marvakis, A., \& Triliva, S. (2006). Special issue: Critical psychology in a changing world (Contributions from different geo-political regions). Annual Review of Critical Psychology, 5. Retrieved February 1, 2015, from www. discourseunit.com/arcp/5

Dafermos, M., Marvakis, A., Mentinis, M., Painter, D., \& Triliva, S. (2013). Critical psychology in a changing world: Building bridges and expanding the dialogue. Annual Review of Critical Psychology, 10. Retrieved February 1, 2015, from wnw.discourseunit.com/arcp/10

Danziger, K. (1997). Naming the mind: How psychology found its language. London: Sage.

Dreier, O. (2008). Psychotherapy in everyday life. Cambridge: Cambridge University Press.

Fox, D., Prilleltensky, I., \& Austin, S. (Eds.). (2009). Critical psychology: An introduction. London: Sage.

Gergen, K. J. (2009). Relational being: Beyond self and community. New York: Oxford University Press.

Giorgi, A. (2009) The descriptive phenomenological method in psychology: A modified Husserlian approach. Pittsburgh: Duquesne University Press.

Grubitzsch, S. (1988). Zur Geschichte der Zeitschrift "Psychologie und Gesellschaftskritik". In G. Rexilius (Ed.), Psychologie als Gesellschaftswissenschaft. Geschichte, Theorie und Praxis kritischer Psychologie. Opladen: Westdeutscher Verlag.
Guzzo, R. S. L. (2014). Conscientization and political change. In T. Teo (Ed.), Encyclopedia of critical psychology (pp.300-303). New York: Springer.

Guzzo, R. S. L. (2015). Critical psychology and the American continent: From colonization and domination to liberation and emancipation. In I. Parker (Ed.), Handbook of critical psychology (pp.406-414). London: Routledge.

Haraway, D. J. (1991). Situated knowledges: The science question in feminism and the privilege of partial perspectives. In D. J. Haraway. Simians, cyborgs, and women: The reinvention of nature (pp.183-201). New York: Routledge.

Harré, R. (1979). Social being: A theory for social psychology. Oxford: Blackwell.

Haug, F. et al. (1999). Female sexualization: A collective work of memory. London: Verso classics.

Hess, D. (1997). Science studies: An advanced introduction. New York: New York University Press.

Højholt, C. (2015). Situated inequality and the conflictuality of children's conduct of life. In E. Schraube \& C. Højholt (Eds.), Psychology and the conduct of everyday life (pp.145-163). London: Routledge.

Holzkamp, K. (1983a). Grundlegung der Psychologie. Frankfurt: Campus Verlag.

Holzkamp, K. (1983b). Theorie und Praxis im Psychologiestudium. Forum Kritische Psychologie, 12, 159-183.

Holzkamp, K. (2013a). Basic concepts of critical psychology. In E. Schraube \& U. Osterkamp (Eds.), Psychology from the standpoint of the subject: Selected writings of Klaus Holzkamp (pp.19-27). Basingstoke: Palgrave Macmillan.

Holzkamp, K. (2013b). The development of critical psychology as a subject science. In E. Schraube \& U. Osterkamp (Eds.), Psychology from the standpoint of the subject: Selected writings of Klaus Holzkamp (pp.28-45). Basingstoke: Palgrave MacMillan.

Holzkamp, K. (2013c). What could a psychology from the standpoint of the subject be? In E. Schraube \& U. Osterkamp (Eds.), Psychology from the standpoint of the subject: Selected writings of Klaus Holzkamp (pp.46-59). Basingstoke: Palgrave MacMillan.

Holzkamp, K. (2013d). Psychology: Social selfunderstanding on the reasons for action in the conduct of everyday life. In E. Schraube \& U. Osterkamp (Eds.), Psychology from the standpoint of the subject: Selected writings of Klaus Holzkamp (pp.233-341). Basingstoke: Palgrave Macmillan.

Holzkamp, K. (2015). Conduct of everyday life as a basic concept of critical psychology. In E. Schraube \& C. Højholt (Eds.), Psychology and the conduct of everyday life (pp.65-98). London: Routledge. 
Hook, D. (Ed.) (2004). Critical psychology. Lansdowne: UCT Press.

Knorr Cetina, K. (1999). Epistemic cultures: How the sciences make knowledge. Cambridge, MA: Harvard University Press.

Kousholt, D. (2015). Collaborative research with children: Exploring contradictory conditions of the conduct of everyday life. In E. Schraube \& C. Højholt(Eds.), Psychology and the conduct of everyday life (pp.241-258). London: Routledge.

Lacerda Jr., F. (2013). Critical psychology in Brazil: A sketch of its history between the end of the 20th century and the early 21st century. Annual Review of Critical Psychology, 10. Retrieved February 1, 2015, from www.discourseunit.com/arcp/10

Latour, B., \& Woolgar, S. (1986). Laboratory life: The construction of scientific facts. Princeton, NJ: Princeton University Press.

Leontyev, A. N. (1981). Problems of the development of the mind. Moscow: Progress Publishers.

Martín-Baró, I. (1994). Writings for a liberation psychology. Cambridge, MA: Harvard University Press.

Marx, K. (1981). Zur Kritik der Hegelschen Rechtsphilosophie. Einleitung. In Marx-Engels-Werke, Band 1 (pp.378-391). Berlin: Dietz Verlag.

Mattes, P. (1985). Die Psychologiekritik der Studentenbewegung. In M. G. Ash \& U. Geuter (Eds.), Geschichte der deutschen Psychologie im 20. Jahrhundert. Opladen: Westdeutscher Verlag.

Motzkau, J., \& Schraube, E. (2015). Kritische Psychologie: Psychology from the standpoint of the subject. In I. Parker (Ed.), Handbook of critical psychology (pp.280-289). London: Routledge.

Nissen, M. (2012). The subjectivity of participation: Articulating social work practice with youth in Copenhagen. Basingstoke: Palgrave MacMillan.

Osterkamp, U. (2009). Knowledge and practice in critical psychology. Theory \& Psychology, 19(2), 167-191.

Osterkamp, U. (2015). "There is no right life in the wrong one": Recognizing this dilemma is the first step out of it. In E. Schraube \& C. Højholt (Eds.), Psychology and the conduct of everyday life (pp.164-175). London: Routledge.

Painter, D., Marvakis, A., \& Mos, L. (2009). German critical psychology: Interventions in honour of Klaus Holzkamp. Theory \& Psychology, 19(2), 139-147.

Papadopoulos, D. (2009). Klaus Holzkamp's critical social science. Theory \& Psychology, 19(2), 161-166.

Papadopoulos, D. (2011). Alter-ontologies: Towards a constituent politics in technoscience. Social Studies of Science, 41(2), 177-201.

Parker, I. (Ed.) (2015). Handbook of critical psychology. London: Routledge.
Reimer, K., \& Markard, M. (2014). German critical psychology. In T. Teo (Ed.), Encyclopedia of critical psychology (pp.784-791). New York: Springer.

Restivo, S. (1988). Modern science as a social problem. Social Problems, 35, 206-225.

Rexilius, G. (Ed.) (1988). Psychologie als Gesellschaftswissenschaft: Geschichte, Theorie und Praxis kritischer Psychologie. Opladen: Westdeutscher Verlag.

Schraube, E. (2003). The politics of TechKnowledge. An experimental moment in psychology. In N. Stephenson, H. L. Radtke, R. Jorna, \& H. J. Stam (Eds.), Theoretical psychology: Critical contributions (pp.39-45). Toronto: Captus University Publications.

Schraube, E. (2013). First-person perspective and sociomaterial decentering: Studying technology from the standpoint of the subject. Subjectivity, 6(1), 12-32.

Schraube, E. (2014). First-person perspective. In T. Teo (Ed.), Encyclopedia of critical psychology (pp.733-736). New York: Springer.

Schraube, E., \& Højholt, C. (Eds.) (2015). Psychology and the conduct of everyday life. London: Routledge.

Schraube, E., \& Osterkamp, U. (Eds.) (2013). Psychology from the standpoint of the subject: Selected writings of Klaus Holzkamp. Basingstoke: Palgrave Macmillan.

Sloan, T. (Ed.) (2000). Critical psychology: Voices for change. Basingstoke: MacMillan.

Stephenson, N., \& Papadopoulos, D. (2006). Analysing everyday experience: Social research and political change. Basingstoke: Palgrave MacMillan.

Teo, T. (2005). The critique of psychology: From Kant to postcolonial theory. New York: Springer.

Teo, T. (Ed.) (2014a). Encyclopedia of critical psychology. New York: Springer.

Teo, T. (2014b). Critical psychology. In T. Teo (Ed.), Encyclopedia of critical psychology (pp.236-248). New York: Springer.

Teo, T. (2015). Critical psychology: A geography of intellectual engagement and resistance. American Psychologist, 70(3), 243-54.

Tolman, C. W. (1994). Psychology, society, and subjectivity. An introduction to German critical psychology. London: Routledge.

Tolman, C. W. (1995). The critical psychological view of subject and subjectivity. In C. W. Tolman, F. Cherry, R. van Hezewijk, \& I. Lubek. (Eds.), Problems of Theoretical Psychology (pp.40-54). Toronto: Captus University Publications.

Tolman, C. W. (2001). Philosophical doubts about psychology as a natural science. In C. D. Green, M. Shore, \& T. Teo (Eds.), The transformation of 
psychology: Influences of 19th-century philosophy, technology, and natural science (pp.175-193). Washington, DC: American Psychological Association.

Tolman, C. W., \& Maiers, W. (Eds.) (1991). Critical psychology: Contributions to an historical science of the subject. Cambridge, MA: Cambridge University Press.

Valsiner, J. (2014). An invitation to cultural psychology. London: Sage.

Vygotzky, L. S. (1927/1997). The historical meaning of the crisis in psychology: A methodological investigation. In R. W. Rieber \& J. Wollock (Eds.),
Problems of the Theory and History of Psychology: Vol.3. The collected works of L. S. Vygotsky (pp.233-243). New York: Plenum Press.

Wertch, J. V. (1991). Voices of the mind: A sociocultural approach to mediated action. Cambridge, MA: Harvard University Press.

Wilkinson, S. (Ed.) (1986). Feminist social psychology: Developing theory and practice. Milton Keynes: Open University Press.

Received: December 2, 2014

Approved: March 26, 2015 
